\title{
Common Pests and Pesticides used in High Value Crops: A Case Study on Some Selected Districts of Nepal
}

\author{
PRAMOD KOIRALA and ANANDA SHOVA TAMRAKAR
}

Central Department of Zoology, Tribhuwan University, Nepal

This study was carried out in eight districts of Nepal to explore the pests, pesticides and other agro-chemicals used in high value crops viz. tea, coffee, honey and vegetables (tomato and brinjal). The study carried out districts for tea were Jhapa and Illam, whereas for vegetables Bara and Kavre. Similarly, honey was studied in Chitwan and Nawalparasi, whereas coffee in Gulmi and Lalitpur. The results revealed that different type of pests were found to be problematic in high value crops production. Loopers were the major pests in tea, borers in coffee, fruit fly in vegetables and mites in beekeeping. Different pesticides and some other agro-chemicals have been found to be used for pest management. Additionally, pesticide residues analysis for selected pesticides was carried out using GC-MS technique. The result of analysis showed that non of pesticides was found at the detection level of 0.7 parts per million.

Key words: High value crops, Pests, Pesticides, Pesticide residue, GC-MS

\section{Introduction}

Pesticides pollution in the environment results disturbance of agri-environment system, residues in food and loss of biodiversity, develops pest resistance, secondary pest outbreak and economic loss to the users (Gupta 2004, Keshavchandran 2009).

Until the 1950s, the people of Nepal remained unaware of modern chemical pesticides and were dependent upon traditional organic techniques for killing pests. Chemical pesticides were first introduced to Nepal in 1952, when Paris green, Gammaxene, and Nicotine sulphates were imported from USA for malaria control. DDT made its first appearance in 1956. This was soon followed by a variety of other organochlorines (in 1950s), organophosphates (in 1960s), Carbamates (in 1970s), and Synthetic pyrethroids (in 1980s) (Koirala et al., 2009b).

Pesticide residue analysis was started in 1978 in Department of Food Technology and Quality Control, Nepal with assistance of FAO. Monitoring results of 1995-2009 for the analysis of 1034 food products showed that $11.2 \%$ food products are contaminated with pesticides (Koirala et al., 2008a). Study on pesticide residue in honey (2007) and in tea (2008) also showed that none pesticide residues were observed for 17 types of pesticides at the detection level of 0.5 parts per million. In 2009, a study on pesticide risk in 15 kinds of Nepalese diet was analyzed for 97 kinds of pesticides. Six pesticides were present (Endosulfan, Chlorpyrifos, Malathion,
Fenvalarate, Cyhalothrin, Permithrin). Pesticide residues were detected in different food commodities like cereals, pulses and vegetables. Among all the food items, vegetables were the maximum contributor for pesticide residues consumption. Multiple pesticide residues were observed in studied foods. The synergistic effect of different types of pesticides may have unusual consequence to consumer health (DFTQC, 2011). The objective of this study is to identify the type of pests and pesticides or other agro-chemicals used in high value crops (Tea, coffee, honey and vegetables).

\section{Materials and Methods}

For four different types of high value crops, eight districts were selected for the study purpose (Table 1). In case of vegetables, tomato and brinjal were studied. These districts were selected from different agro-climatic zones because pests in the different agro-climatic zones are different and thus use of pesticides applied could be different. The Village Development Committee (VDC) from the selected districts were taken purposively based on the criteria of highest production statistics of high value crops. The 192 farmers involved in the production of the high value crops were selected for the study purpose. There were altogether 24 samples of high value crops were taken for pesticide residues analysis.

\footnotetext{
*Corresponding author, E-mail: pramodkoirala2002@yahoo.com
} 
Table 1. Sampling frame

\begin{tabular}{|c|c|c|c|c|c|}
\hline SN & Samples & Study districts & $\begin{array}{c}\text { Study unit at } \\
\text { household level }\end{array}$ & $\begin{array}{c}\text { No of } \\
\text { households } \\
\text { visited }\end{array}$ & $\begin{array}{l}\text { Sample collection for } \\
\text { laboratory analysis }\end{array}$ \\
\hline 1 & Tea & Jhapa, Illam & 3 VDCs, 4 wards & 48 & 6 \\
\hline 2 & Coffee & Gulmi, Lalitpur & 3 VDCs, 4 wards & 48 & 6 \\
\hline 3 & Vegetables & Kavre, Bara & 3 VDCs, 4 wards & 48 & 6 \\
\hline 4 & Honey & $\begin{array}{l}\text { Nawalparasi, } \\
\text { Chitwan }\end{array}$ & 3 VDCs, 4 wards & 48 & 6 \\
\hline Total & & & & 192 & 24 \\
\hline
\end{tabular}

Sampling process- Sampling process including criteria for sampling has been shown as follows;

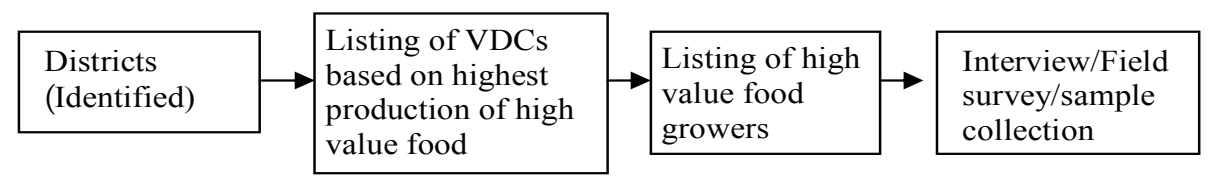

Table 2. Sample code of different food commodities

\begin{tabular}{|c|c|c|}
\hline Commodi & Sample Code & Sample Code \\
\hline Tea & J 1-Tea sample from Bhadrapur municipality Jhapa & IL 2- Tea sample from Jasbire VDC Ilam \\
\hline & J 2- Tea sample from Bahudangi VDC Jhapa & IL 3- Tea sample from Fikkal VDC Ilam \\
\hline & J 3- Tea sample from Haldabari VDC Jhapa & IL1- Tea sample from Mangalbare VDC Ilam \\
\hline $\begin{array}{l}\text { Vegetables } \\
\text { (Tomato) }\end{array}$ & $\begin{array}{l}\text { SN 1- Tomato sample from Nala, Kavre } \\
\text { SP 1- Tomato sample from Pachkhal, Kavre }\end{array}$ & $\begin{array}{l}\text { SM 1- Tomato sample from Mahadevbeshi, } \\
\text { Kavre }\end{array}$ \\
\hline Brinjal & DU1- Brinjal sample from Bariyarpur, Bara & DU2- Brinjal sample from Inaruwa, Bara \\
\hline & ple from Banjaria; Bara & \\
\hline Coffee & CGR - Coff & \\
\hline & CGT- Coffee sample from Thanapati VDC Guln & Gimdi VD \\
\hline & $\begin{array}{l}\text { CLT - Coffee sample from Thula Durlung } \\
\text { VDCLalitpur }\end{array}$ & CLP Coffee sample from VDC Pyutar Lalitpur \\
\hline Honev & HCC1- Honev sample from Chitwan, Chiuri & HNM 2- Honev sample from Nawalparasi. \\
\hline & & Centrifuge for 5 min at $3000 \mathrm{RPM}$ \\
\hline & & ake supernatant in a vial and freeze for fatty sample \\
\hline
\end{tabular}

a Mini-Multiresidue Method for the Analysis of Pesticide Residues. A mini-multiresidue method for the analysis of pesticide residues (QuEChERS) was used. The sample extraction process is as follows;

Weigh $10 \mathrm{~g}$ sample into $50 \mathrm{ml}$ centrifuge tube (with screw cap)

Add $10 \mathrm{ml}$ of acetonitrile and then ISTD solution and shake vigorously for $1 \mathrm{~min}$

$$
\downarrow
$$

$4 \mathrm{~g}$ magnesium sulfate $1 \mathrm{~g}$ sodium chloride $1 \mathrm{~g}$ trisodiumcitrate dihydrate and $0.5 \mathrm{~g}$ of sodium dihydrogencitrate sesquihydrate shake well add 600 micro liter of $5 \mathrm{~N}$ sodium hydroxide for acidic samples and shake vigorously

Add $1 \mathrm{ml}$ supernatant in sorbent and shake well for $30 \mathrm{sec}$; centrifuge for $5 \mathrm{~min}$ at $3000 \mathrm{RPM}$

Add $1 \mathrm{ml}$ supernatant in sorbent

$$
\downarrow
$$

Transfer and supernatant to vial after maintaining $\mathrm{pH}$

GCMS condition- EPA methods 508 Pesticide using Rtx -5 and modified methods: Oven $60^{\circ} ; 25^{\circ} / \mathrm{min}: 150^{\circ}(1 \mathrm{~min})$; $3^{\circ} / \mathrm{min}: 200^{\circ}(1 \mathrm{~min}) ; 8^{\circ} / \mathrm{min}: 290^{\circ}(8 \mathrm{~min})$; Ion source $250^{\circ}$; Detector: $280^{\circ}$; Carrier gas: Helium; SIM.

\section{Results and Discussion}

Among the studied high value crop growers, majority (60 \%) of respondents were in between the age group of 40 to 50 years. 
Majority $(60 \%)$ of respondents were with other business along with high value crop production. $30 \%$ were with qualification intermediate or more. Among the respondents, cash crop income (income for tea, coffee, vegetables and honey) contributes 20 to 25 depending on type of crops. It was observed that rise in agriculture income of farmers; there were more education level attainment among the family members. $(\mathrm{p}<0.05)$.
The area covered by commercially cultivate crops were (for tea $25 \%$ coffee $10 \%$ and vegetables $20 \%$ ). The highest average income per farmer was found to be NRs 30,000 for tea farmers followed by NRs 15,000 in coffee, NRs 10,000 for vegetables and NRs 7,000 for honey. The average duration of stay time to farmers at the field were- beekeeping $8 \mathrm{hrs}$, vegetables 7 hrs, tea 5 hrs and coffee 4 hrs daily.

Table 3. Socio-economic aspects of high value crop growers

\begin{tabular}{|c|c|c|c|c|c|c|c|c|}
\hline \multirow[t]{2}{*}{ Particulars } & \multicolumn{2}{|c|}{ Tea } & \multicolumn{2}{|c|}{ Vegetable } & \multicolumn{2}{|c|}{ Coffee } & \multicolumn{2}{|c|}{ Honey } \\
\hline & $\begin{array}{c}\text { Total } \\
\text { number }\end{array}$ & $\%$ & $\begin{array}{c}\text { Total } \\
\text { number }\end{array}$ & $\%$ & $\begin{array}{c}\text { Total } \\
\text { number }\end{array}$ & $\%$ & $\begin{array}{c}\text { Total } \\
\text { number }\end{array}$ & $\%$ \\
\hline \multicolumn{9}{|l|}{ Type of family } \\
\hline Joint & 30 & 63 & 30 & 63 & 30 & 63 & 30 & 63 \\
\hline Nuclear & 15 & 31 & 14 & 29 & 14 & 29 & 15 & 31 \\
\hline Extended & 3 & 6 & 4 & 8 & 4 & 8 & 3 & 6 \\
\hline Total & 48 & 100 & 48 & 100 & 48 & 100 & 48 & 100 \\
\hline \multicolumn{9}{|l|}{ Religion } \\
\hline Hindu & 35 & 73 & 40 & 83 & 45 & 94 & 43 & 90 \\
\hline Buddhist & 8 & 17 & 5 & 10 & 2 & 4 & 1 & 2 \\
\hline Others & 5 & 10 & 3 & 7 & 1 & 2 & 4 & 8 \\
\hline Total & 48 & 100 & 48 & 100 & 48 & 100 & 48 & 100 \\
\hline \multicolumn{9}{|l|}{ Age of the respondents } \\
\hline 30 or less & 5 & 10 & 5 & 10 & 5 & 10 & 12 & 25 \\
\hline 30 to 40 years & 5 & 10 & 15 & 31 & 15 & 31 & 21 & 44 \\
\hline 40 to 50 years & 30 & 63 & 25 & 52 & 25 & 52 & 10 & 21 \\
\hline Above 50 years & 8 & 17 & 3 & 6 & 3 & 7 & 5 & 10 \\
\hline Total & 48 & 100 & 48 & 100 & 48 & 100 & 48 & 100 \\
\hline \multicolumn{9}{|l|}{ Profession } \\
\hline Agriculture solely & 20 & 42 & 24 & 50 & 21 & 44 & 15 & 31 \\
\hline $\begin{array}{l}\text { Agriculture with private } \\
\text { business }\end{array}$ & 10 & 21 & 9 & 19 & 12 & 25 & 21 & 44 \\
\hline $\begin{array}{l}\text { Agriculture with government } \\
\text { worker }\end{array}$ & 8 & 17 & 7 & 15 & 5 & 10 & 3 & 7 \\
\hline Agriculture with self employed & 10 & 21 & 8 & 16 & 10 & 21 & 9 & 18 \\
\hline $\begin{array}{l}\text { Total } \\
\text { Education level }\end{array}$ & \multicolumn{7}{|c|}{ Education level } & 100 \\
\hline SLC or below & 20 & 42 & 35 & 73 & 20 & 42 & 15 & 31 \\
\hline SLC to intermediate & 20 & 42 & 5 & 10 & 20 & 42 & 20 & 42 \\
\hline Bachelors or above & 8 & 16 & 8 & 17 & 8 & 16 & 13 & 27 \\
\hline Total & 48 & 100 & 48 & 100 & 48 & 100 & 48 & 100 \\
\hline \multicolumn{9}{|l|}{ Annual Agriculture income } \\
\hline Up to $\mathrm{Nrs} 50,000$ & 10 & 21 & 15 & 31 & 28 & 58 & 20 & 41 \\
\hline Nrs 50000 to $1,00,000$ & 5 & 10 & 16 & 33 & 15 & 31 & 12 & 25 \\
\hline Nrs $1,00,000$ to $1,50,000$ & 10 & 21 & 10 & 21 & 3 & 7 & 13 & 27 \\
\hline More than $1,50,000$ & 23 & 48 & 7 & 15 & 2 & 4 & 3 & 7 \\
\hline Total & 48 & 100 & 48 & 100 & 48 & 100 & 48 & 100 \\
\hline
\end{tabular}

Analysis of pesticide residues- In total, 24 samples of high value crops were collected from eight different districts of Nepal. 6 samples of tea were collected from Jhapa and Illam were collected from Bara and Kavre. Similarly, six 6 samples were collected from Gumli and Lalitpur and 6 samples of honey were collected from Chitwan and Nawalparasi. These high value crops were analyzed for pesticides by using GC- 
Table 4. Analytical result of pesticide residue level in Tea

\begin{tabular}{|c|c|c|c|c|}
\hline Pesticide analyzed & $\begin{array}{l}\text { Tea samples } \\
\text { (J1, J2, J3 } \\
\text { IL1, IL2, IL3) } \\
\end{array}$ & $\begin{array}{l}\text { Vegetables } \\
\text { (SN } 1 \text { SM } 1 \text { SP 1, DU1 } \\
\text { DU2 DU3) }\end{array}$ & $\begin{array}{l}\text { Coffee } \\
\text { (CGR, CGH, LGC, } \\
\text { CGT, CLT, CLP) }\end{array}$ & $\begin{array}{l}\text { Honey (HCC1, HNM 2, } \\
\text { HCC 3, HNJ 1, HCR 2, } \\
\text { HNM 3) }\end{array}$ \\
\hline Aldrin & $\mathrm{ND}$ & ND & $\mathrm{ND}$ & ND \\
\hline$\alpha-\mathrm{BHC}$ & ND & ND & ND & ND \\
\hline ß-BHC & ND & ND & ND & ND \\
\hline$\gamma$-BHC (Lindane) & ND & ND & ND & ND \\
\hline$\alpha$-Chlordane (cis) & ND & ND & ND & ND \\
\hline$\gamma$-Chlordane (trans) & ND & ND & ND & ND \\
\hline $4,4^{\prime}-\mathrm{DDD}$ & ND & ND & ND & ND \\
\hline 4,4'-DDE & ND & ND & ND & ND \\
\hline $2,4^{\prime}-\mathrm{DDT}$ & ND & ND & ND & ND \\
\hline 4,4'-DDT & ND & ND & ND & ND \\
\hline Dieldrin & ND & ND & ND & ND \\
\hline A-endosulfan I & ND & ND & ND & ND \\
\hline B-endosulfan II & ND & ND & ND & ND \\
\hline Endosulfan sulfate & ND & ND & ND & ND \\
\hline Endrin & ND & ND & ND & ND \\
\hline Heptachlor & ND & ND & ND & ND \\
\hline Heptachlor epioxide & ND & ND & ND & ND \\
\hline Hexachlorobenzene & ND & ND & ND & ND \\
\hline Oxychlordane & ND & ND & ND & ND \\
\hline
\end{tabular}

Note: ND - At detection level of $0.7 \mathrm{mg} / \mathrm{kg}$

MS. The results of pesticide residues analysis showed that none of the pesticides were found at the detection level of 0.7 parts per million. The list of pesticide analyzed is given in Table 4.

Pests problem were the highest in tea followed by vegetables, coffee and honey. The common pests in high value crops along with their management practices are given in table (Table 4). According to respondents, the damage of different crops by pests if not pesticides and agro-chemicals applied were $30 \%$ in tea, $25 \%$ in vegetables, coffee $15 \%$ and honey $20 \%$. Majority of farmers were using pesticides and other agrochemicals use once started farming. The average duration of pesticide and other agro-chemicals use in tea was $19 \mathrm{y} / \mathrm{rs}$, vegetables 13 yrs and in coffee was 10 yrs and honey 7 yrs. Farmers were using twenty 7 types of pesticides in tea, for vegetables twenty 4 types of pesticides and agro-chemicals were found to be applied. In case of coffee no pesticides and agro-chemicals have been found to be applied but for honey 6 agro-chemicals were in practice. Since, farmers were found to be dissatisfied with IPM approach for pest control, IPM practice in controlling pests were less practiced. The current field pest management practice like Integrated Pest Management (IPM) has adopted in tea $10 \%$, Coffee $30 \%$, honey $20 \%$, vegetables $10 \%$ ).

Farmers were aware of health hazard of pesticides/agro- chemicals ( $95 \%$ tea, $80 \%$ vegetables, $80 \%$ coffee, $75 \%$ honey). Interestingly, only male were found to be handling of pesticides and agro-chemicals. No any new pests were reported in crops that could damage the high value crops significantly. Additionally, the training to decrease pesticide use in agriculture (such as IPM) and use of alternatives pesticide such as biopesticides and equipment handling for safety were found to be demanded by farmers.

The most common types of pests and diseases as well as pesticides used in in different high value crops are given in Table 5.

\section{Conclusion}

Different pests and diseases were creating problems for agro farmers, who were involved in high value crop production. Field survey results reveled that there were different pesticides used in tea and vegetables to control different types of pests. However, in coffee and honey no pesticides were reported to be applied. Banned pesticides were not observed in the field survey neither in the laboratory analysis result. In other hand, the results revealed that loopers in tea, borers in coffee, fruit fly in vegetables and mites in beekeeping were the major pests. Pesticides and some other agro-chemicals used was one of the most applied techniques for the management of pests. Pesticide residue analysis result in high value crops showed that it was below the detection level of $0.7 \mathrm{ppm}$ in all analyzed samples. 
Table 5. Common Pests in high value crops and their management practices

\begin{tabular}{|c|c|c|}
\hline & Pests/ Diseases & $\begin{array}{l}\text { Common Pesticides Applied /Management } \\
\text { practices }\end{array}$ \\
\hline \multicolumn{3}{|c|}{ Common pests/disease in Brinjal } \\
\hline 1. & Brinjal fruit and shoot borer & $\begin{array}{l}\text { Methyl parathion, Rogor, Thiodan, Devicyper, Jackpot } \\
\text { 10, Nurami, Ammo, Devikol }\end{array}$ \\
\hline 2 & White fly & Nuvan \\
\hline 3 & Aphid & Devikol, Dhanuka, Gajani, \\
\hline 4 & Melon thrips & Dhanuka, \\
\hline 5 & Army worm & Super lethal, Dolphin \\
\hline 6 & Cut worm & Gajani \\
\hline 7 & Spotted beetle & Anumida \\
\hline \multicolumn{3}{|c|}{ Common Pests/Diseases in tomato } \\
\hline 1 & Helicoverpa & Decis, Silcord, Dolphin, Superlethal, Ammo \\
\hline 2 & Aphid & Devikol, Dhanuka, Gajani, \\
\hline 3 & Leaf minor & Rogor, Thiodan, Devicyper, Record, Super D \\
\hline 4 & White fly & Nuvan \\
\hline 5 & Late blight & Diethan M 45, Krilaxyl \\
\hline 6 & Leaf curl virus & Nuvan \\
\hline 7 & Wilting & Anumida \\
\hline 8 & White grub & Methyl parathion, Devimono \\
\hline 9 & Brown rot & Diethan M 45 \\
\hline \multicolumn{3}{|c|}{ Common pests/diseases in Tea } \\
\hline 1 & $\begin{array}{l}\text { Green Fly, Looper, Red slugs, Thrips Aphids, } \\
\text { Flushwormes etc. }\end{array}$ & Thiodane, Orthene \\
\hline 2 & Tea Mosquito, Thrips & Farsa, Gem \\
\hline 3 & Jassids, Aphids & Flash, Kinalaux \\
\hline 4 & $\begin{array}{l}\text { Catterpillar, thrips, Red spider, pink scarlet } \\
\text { and purple mite }\end{array}$ & Omite, Ripcord \\
\hline 5 & $\begin{array}{l}\text { Green Fly, halopaltis, Thips, Looper, Jasids, } \\
\text { Caterpillar }\end{array}$ & Monosil \\
\hline 6 & Tea mosquito & Malathion \\
\hline 7 & Thrips, Aphides, worms etc. & Propanophos \\
\hline 8 & Mites and other insect & Emidagold, Josh \\
\hline 9 & Tea mosquito, Jassids, Fly Iarvae & Nuvan \\
\hline 10 & $\begin{array}{l}\text { Mosquitos, fly larvae, Aphids other insect and } \\
\text { termites }\end{array}$ & Durmet \\
\hline 11 & $\begin{array}{l}\text { Dicot/Broad leafs, of Dicot/Broad Leafs, } \\
\text { Prevent Pre and post emergence of weeds, } \\
\text { Broadleaf weeds }\end{array}$ & Gramoxone, Round up, $2.4 \mathrm{D}$ \\
\hline 12 & Red Rust & Blitox \\
\hline 13 & Fungus Infestation & Captaf \\
\hline 14 & Wide range of Foliage disease & Dithane, PenncoZeb \\
\hline 15 & Fungus disease and infestation & Unilux \\
\hline 16 & Mite & Dicofoll, Devicol \\
\hline 17 & Mites, spider & Omite, Sulphex \\
\hline \multicolumn{3}{|c|}{ Common pests/disease in coffee } \\
\hline 1 & White stem borer & Manual clearance \\
\hline 2 & Red stem borer & Manual clearance \\
\hline 3 & Coffee rust & Manual clearance \\
\hline 4 & Goad weed (Ageratum conyzoids) & Manual clearance \\
\hline 5 & Jungle rice (Echinoochloa spp) & Manual clearance \\
\hline \multicolumn{3}{|c|}{ Common pests/disease in honey } \\
\hline 1 & Tropilaelaps cleareae & Apistan, formic acid \\
\hline 2 & Varroa jacobsonii & Formic acid and sulfur smoking \\
\hline 3 & European foulbrood & Teramycin and tetracyclin \\
\hline 4 & Acarapis woodi & Formic acid and sulfur \\
\hline 4 & Nosema & Sulfur smoking, camphous \\
\hline 5 & Wax moth and sornet & Prevention/management \\
\hline
\end{tabular}




\section{References}

Anastassiades M., S. J. Lehotay, D. Stajnbaher, F. J. Schenck (2003). Fast and Easy Multiresidue Method Employing Acetonitile Extraction/Partitioning and "Dispersive Solid-Phase Extraction" for the Determination of Pesticide Residues in Produce, J.A.O.A.C. Int., 86 412431 exposure to pesticides in agriculture" Med Lav MarApr; 97(2);430-7.

DFTQC, (2011). Study on Total Diet Study on Nepalese Diet, Unpublished report, DFTQC.

Gupta P. K. (2004 ). Pesticide use in India. J Toxicoll, May 20; 198(1-3): 83-90.

Keshavachandran C. N., Fareed M., Pathak M., Bihari V., Mathur N. and Shristava A.K. (2009). Adverse health effects of pesticides in agrarian populations of developing countries. Environ Contam Toxicol;200:33-52.
Koirala P., Dhakal S., Tamrakar A.S. (2009). Pesticides and Food Safety Issues in Nepal, The Journal of Agriculture and Environment, Ministry of Agriculture and Cooperatives, 10:96-100.

Koirala P., Dahal N.R., Dahal S., Bhandari M.R., Lama J.P. (2008a). Pests Ubiquitous and Use of Pesticides in Vegetables in Eastern Region of Nepal, DFTQC bulletin.

Koirala P., Khadka S. Dhakal S., Lama J.P. (2008b ). Tea pests and Pesticides used in Tea in Nepal. JFSTN, 3: 11-15.

Rissato Sandra R., Mário S. Galhiane, Marcos V. de Almeida, Marli Gerenutti and Benhard M. Apon (2007). Multiresidue determination of pesticides in honey samples by gas chromatography-mass spectrometry and application in environmental contamination. Food Chem. 101(4): 1719-1726. 